\title{
Socio-Hydrological Approach to the Evaluation of Global Fertilizer Substitution by Sustainable Struvite Precipitants from Wastewater
}

\author{
Dirk-Jan Daniel Kok ${ }^{1}$, Saket Pande ${ }^{1}$, Angela Renata Cordeiro Ortigara ${ }^{2}$, Hubert Savenije ${ }^{1}$, and \\ Stefan Uhlenbrook ${ }^{1,2}$ \\ ${ }^{1}$ Department of Water Management, Delft University of Technology, Delft, the Netherlands \\ ${ }^{2}$ World Water Assessment Programme, UNESCO, Perugia, Italy \\ Correspondence: Dirk-Jan Daniel Kok (d.d.kok@student.tudelft.nl)
}

Received: 25 July 2017 - Accepted: 3 October 2017 - Published: 1 February 2018

\begin{abstract}
Despite Africa controlling the vast majority of the global phosphate it also faces the greatest food shortages - partially due to a lack of access to the fertilizer market. A more accessible source of phosphorus comes from wastewater flows, which is currently lost through the discharge to open surface waters. Analysing the potential phosphorus production of urban and livestock wastewater in meeting partial agricultural demand for phosphorus can improve food security, reduce consumption of unrenewable phosphorus, reduce pollution, and aid the transitioning to a circular economy. In this study, a global overview is provided where a selection of Pproduction and P-consumption sites have been determined using global spatial data. Distances, investment costs and associated carbon footprints are then considered in modelling a simple, alternative trade network of struvite phosphorus flows. The network reveals potential for increasing the phosphorus security through phosphorus recycling in particularly the South Africa, Lake Victoria and Nigeria regions. Given Africa's rapid urbanization, phosphorus recovery from wastewater will prove an important step in creating sustainable communities, protecting the environment while improving food security, and so contributing to the United Nations 2030 Agenda for Sustainable Development.
\end{abstract}

\section{Introduction}

Phosphorus $(\mathrm{P})$ is an element necessary for the development of crops as it forms a key, structural component of DNA and RNA. It is applied in the form of single or triple superphosphate, or mono-Ammonium or di-Ammonium Phosphate (DAP) fertilizers which are both easy to transport, to distribute over fields and are readily absorbed by plants. The most essential source for the production of phosphorus fertilizer is phosphate ore. Some authors predict a peak production of phosphate ore could occur as early as 2030 (Cordell et al., 2009), or that extractable mineral $P$ resources will become scarce or exhausted within the next 50 to 100 years (Steen, 1998; Smil, 2000; van Vuuren et al., 2010). This prospect threatens the food security situation of Sub-Saharan Africa (SSA), as nearly $75 \%$ of SSA's agricultural soils are nutrient deficient and so already contributing significantly to the crop yield gaps (IFDC, 2006). The immediate results of phosphate rock depletion will be a further reduction of the accessibility to fertilizers by small-holder and sustenance farmers that comprise areas already coping with food shortages.

\subsection{Potential to Recover}

Despite the issues surrounding phosphorus demands and yield gaps, there currently exists no financially attractive recovery technology for the enormous phosphorus recovery potential from livestock (Schoumans et al., 2015), while urban recovery is often also limited due to financial constraints. The competitive position of the relatively expensive, recovered phosphorus is improving, however, as over the past 15 years the phosphorus price of di-Ammonium Phosphate (DAP; Index Mundi, 2017) has increased from $665\left[\mathrm{USD} \mathrm{t}^{-1}\right.$ ] to $1552\left[\mathrm{USD} \mathrm{t}^{-1}\right.$ ]. In that same period, the 
price has been as high as 5217 [USD t ${ }^{-1}$ ] during the economic crisis around 2008 and as low as $656\left[\mathrm{USD} \mathrm{t}^{-1}\right.$ ] in 2002 (Index Mundi, 2017). Given these price trends, and that the will, the technology and the knowledge are there to facilitate the largescale implementation of phosphorus recovery, it is important that investigation is done as to what such a development may come to look like. This study aims to identify and connect those areas where there exists a high potential for the recovery of a sustainable phosphorus products from urban and livestock wastewater, to those areas of high agricultural demand.

\section{Materials and Methods}

Using population density maps (CIESIN, 2016; Robinson et al., 2014) and globally generalized phosphorus excretion rates (Gilmour et al., 2008; Barker et al., 2001; CBS, 2014), a crude mapping of phosphorus production sites is carried out at global scale. Apart from these sustainable sources, a total of $5.2\left[\mathrm{mt} \mathrm{a}^{-1}\right]$ P-production from major African mines is included also (USGS, 2007). The demand for phosphorus is assessed through crop harvested area maps for 6 major crops that account for approximately $50-56 \%$ of the global phosphorus fertilizer consumption (Heffer and Prud'homme, 2008). The $P$ demands for maize, wheat, rice, sorghum, soy bean, and potato are approximated for the optimal, but waterconstrained, yield as determined through the transpiration deficit method (Steduto et al., 2012). The associated phosphorus requirement for this yield is determined through a linear regression between yield and P-fertilizer application. These demands are then proportionally scaled up to match the global agricultural demand of all crops of $16\left[\mathrm{Mt} \mathrm{a}^{-1}\right]$. The remaining production and demand sites are connected to each other through a network. The creation process accounts for generalized struvite precipitation costs by Eq. (1),

$f_{\min }^{i}=\frac{P_{\mathrm{m}} \times R_{\mathrm{mp}}+B^{s}}{S_{\mathrm{PT}}}-S_{\mathrm{s}}$

where $f_{\text {min }}^{i}$ is the minimum price for phosphorus for node $i$ [USD t ${ }^{-1}$ ]; $P_{\mathrm{m}}$ is the price of magnesium [USD t ${ }^{-1}$ ]; $R_{\mathrm{mp}}$ is the ratio of magnesium required per ton of phosphorus; $B^{i}$ fixed operational cost [USD]; $S_{\mathrm{PT}}$ is the total phosphorus production potential [t]; and $S_{\mathrm{s}}$ is the minimum scaling cost savings from struvite precipitation, 620 [USD t ${ }^{-1}$ ] (Shu et al., 2006). Similarly, maximum prices that demand nodes are able to pay are determined roughly through Eq. (2).

$f_{\max }^{n}=\frac{Y_{\mathrm{opt}}^{n} \times C_{a}^{n}}{P_{\mathrm{opt}}^{n}} \times R^{n}$

where $f_{\max }^{n}$ is the max price for phosphorus [USD t ${ }^{-1}$ ]; $Y_{\mathrm{opt}}^{n}$ is the optimal yield [ $\mathrm{tha}^{-1}$ ]; $C_{a}^{n}$ is the crop price in year $a$ [USD t ${ }^{-1}$ ]; $P_{\text {opt }}$ is the optimum fertilizer dosage rate (equal to P-demand for optimal yield) [ $\left[\mathrm{tha}^{-1}\right.$ ]; and $R^{n}$ is the ratio of

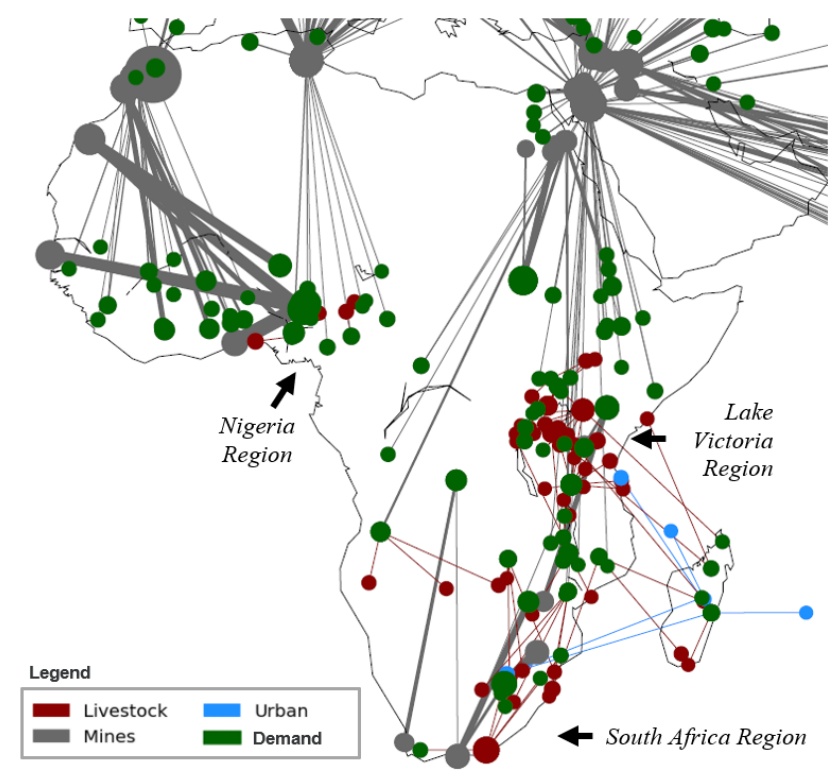

Figure 1. Dominant network pattern of potential trade in recovered $\mathrm{P}$ (on top of rock based $\mathrm{P}$ ).

fertilizer cost to total costs [-], for crop $n$. The transportation costs are determined with as-the-crow-flies distances with a land transport cost equation as a basis. In this are considered: the price of diesel, a labour wage of $17\left[\mathrm{USDh}^{-1}\right.$ ], an average velocity of $80\left[\mathrm{~km} \mathrm{~h}^{-1}\right]$, a load capacity of 60 tonnes $(2 \times 30)$, and a fuel efficiency of $0.53\left[\mathrm{~L} \mathrm{~km}^{-1}\right]$ at capacity. The model is run for a future $\mathrm{P}$-supply scenario of mine production supplemented by sustainable sources that are introduced individually when market prices make their recovery feasible.

\section{Results}

While the network analysis is conducted globally for the year 2005, only outcomes relevant for continental Africa are discussed here. The network reveals potential for increasing the phosphorus security of particularly Rwanda, Burundi, Kenya, Tanzania, Uganda, Malawi, South Africa, and Nigeria, through phosphorus recycling (Fig. 1).

Approximate phosphorus production potentials of 130 $\left[\mathrm{kt} \mathrm{a}^{-1}\right]$ and $1300\left[\mathrm{kt} \mathrm{a}^{-1}\right]$ from concentrated urban and livestock areas respectively are determined for continental Africa. The phosphorus demand for optimal, water restricted yield in Africa for the six major crops is approximately 1 $\left[\mathrm{mt} \mathrm{a}^{-1}\right]$, which equals $12 \%$ of the global crop demand. Continental wide struvite precipitation from major urban рориlation centres can theoretically then satisfy a maximum of $13 \%$ of the agricultural demand for these crops. The Lake Victoria and South African regions show a higher than average density of fluxes in sustainable trade. The first areas to offer competitive sustainable phosphorus lie in these re- 
gions, entering the market around prices of $600\left[\mathrm{USD} \mathrm{t}^{-1}\right] \mathrm{P}$. The African market in recoverables, i.e. recycled phosphorus, expands further at 800 [USD t ${ }^{-1}$ ], and continues to grow in smaller amounts at higher prices.

\section{Discussion and Conclusion}

The model offers a simple framework for network assessment of optimal global phosphorus trade and maximum phosphorus potentials. Provided it is at global scale and that we have only discussed outcome relevant for Africa, however, the study is also superimposed with many generalisations and assumptions that introduce many side notes to its validation. Inaccuracies in assessing the urban and livestock production potentials due to generalization of throughput figures, the inconsideration for trans-Atlantic trade, the as-thecrow-flies distance method, assumptions of free trade, as well as the cost equation assuming land transport costs per kilometre - disregarding cheaper costs for shipping - all possibly contribute to an over approximation of the market prices.

Sustainable products become more competitive with higher market prices for phosphorus. Higher market prices are created as the price of fuel rises, mine exploitation costs increase and total supply decreases. Sustainable sources already have a potential to be competitive in South Africa, the Victoria Lake region and Nigeria given the close proximity of production and demand nodes of significant supply and demands, and their relative distance from the world's largest phosphate mines. The introduction of recovered products to the market will result in: (1) an increase in access to fertilisers within Africa and elsewhere, (2) lower phosphorus cost, (3) cause for a significant reduction in transport associated emissions, (4) stimulate the treatment of wastewater, and (5) contribute to improving food security.

Data availability. This study's produced datasets are no longer available with the updating of the model. The complete and updated datasets are available from the corresponding author on request.

Competing interests. The authors declare that they have no conflict of interest.

Special issue statement. This article is part of the special issue "Water security and the food-water-energy nexus: drivers, responses and feedbacks at local to global scales". It is a result of the IAHS Scientific Assembly 2017, Port Elizabeth, South Africa, 10-14 July 2017.

Edited by: Graham Jewitt

Reviewed by: Rebecca Sindall

\section{References}

Barker, J. C., Hodges, S. C., and Walls, F. R.: Livestock Manure Production Rates and Nutrient Content, 1-4, 2001.

CBS (Centraal Bureau voor de Statistiek): Dierlijke mest en mineralen 2013, The Hague: Centraal Bureau voor de Statistiek, available at: https://www.cbs.nl/-/media/imported/documents/ 2014/49/2014-dierlijke-mest-en-mineralen-2013-pub.pdf (last access: 11 October 2016), 2014.

CIESIN (Center for International Earth Science Information Network): Columbia University, Gridded Population of the World, Version 4 (GPWv4): Population Density, https://doi.org/10.7927/H4NP22DQ, 2016.

Cordell, D., Drangert, J.-O., and White, S.: The story of phosphorus: Global food security and food for thought, Glob. Environ. Change, 19, 292-305, https://doi.org/10.1016/j.gloenvcha.2008.10.009, 2009.

Gilmour, D., Blackwood, D., Comber, S., and Thornell, A.: Identifying human waste contribution of phosphorus loads to domestic wastewater, Proceedings at the 11th International Conference on Urban Drainage, Held in Edinburgh, Scoltand, UK, 1-10, https://web.sbe.hw.ac.uk/staffprofiles/bdgsa/11th_International_ Conference_on_Urban_Drainage_CD/ICUD08/pdfs/740.pdf (last access: 27 November 2017), 2008.

Heffer, P. and Prud'homme, M.: Medium-Term Outlook for Global Fertilizer Demand, Supply and Trade 2008-2012, 76th IFA Annual Conference Vienna (Austria), 19-21 May 2008.

IFDC (International Center for Soil Fertility and Agricultural Development): gricultural Production and Soil Nutrient Mining in Africa: Implications for Resource Conservation and Policy Development, IFDC: Muscle Shoals, Alabama 35662, USA, 2006.

Index Mundi Commodity Price Indices: DAP Fertilizer, available at: http://www.indexmundi.com/commodities/, last access: 15 July 2017.

Robinson, T. P., William Wint, G. R., Conchedda, G., van Boeckel, T. P., Ercoli, V., Palamara, E., and Gilbert, M.: Mapping the global distribution of livestock, PLoS ONE, 9, e96084, https://doi.org/10.1371/journal.pone.0096084, 2014.

Schoumans, O. F., Bouraoui, F., Kabbe, C., Oenema, O., and van Dijk, K. C.: Phosphorus management in Europe in a changing world, Ambio, 44, 180-192, https://doi.org/10.1007/s13280014-0613-9, 2015.

Shu, L., Schneider, P., Jegatheesan, V., and Johnson, J.: An economic evaluation of phosphorus recovery as struvite from digester supernatant, Bioresource Technol., 97, 2211-2216. https://doi.org/10.1016/j.biortech.2005.11.005, 2006.

Smil, V.: Phosphorus in the environment: Natural flows and human interferences, Annu. Rev. Energ. Env., 25, 53-88, https://doi.org/10.1146/annurev.energy.25.1.53, 2000.

Steen, I.: Management of a non-renewable resource, Phosphorus and Potassium, 217, 25-31, 1998.

Steduto, P., Hsiao C., T., Fereres, E., and Raes, D. FAO Irrigation and Drainage Paper: Crop Yield Response to Water, Rome: Food and Agriculture Organization of the United Nations (FAO), 2012.

USGS (United States Geological Survey): Mineral Commodity Summary Phosphate Rock, 2007. 
Van Vuuren, D. P., Bouwman, A. F., and Beusen, A. H. W.: Phosphorus demand for the 1970-2100 period: A scenario analysis of resource depletion, Glob. Environ. Change, 20, 428-439. https://doi.org/10.1016/j.gloenvcha.2010.04.004, 2010. 